\title{
ДО ПИТАННЯ ПРО ІННОВАЦІЙНІ МЕТОДИ ОБЛІКУ В РОБОТІ МЕДСЕСТЕР ЗА УМОВ РЕФОРМУВАННЯ ГАЛУЗІ
}

\author{
О. І. Гарасимів
}

Борщівська центральна районна клінічна лікарня

У статті йдеться про електронний метод обліку як інновацію в роботі медсестер за умов реформування галузі охорони здоров’я. Обгрунтовано підвищення результативності діяльності закладу охорони здоров’я за умов таких інноваційних впроваджень.

\section{TO THE ISSUE OF INNOVATIVE ACCOUNTING METHODS IN THE WORK OF A NURSE IN THE CONDITIONS OF REFORMING THE HEALTH SECTOR}

\section{O. I. Harasymiv}

\section{Borshchiv Central District Clinical Hospital}

The article deals with the electronic method of accounting as an innovation in the work of nurses in the context of reforming the health sector. The increase of the activity of the health care institution under the conditions of such innovative implementations is substantiated.

Вступ. Стає все очевидніше, що сучасна система охорони здоров'я буде зламана, а разом із нею і всі стереотипи, функції та звичний уклад діяльності медсестри. Чого очікувати в перспективі передбачити сьогодні надзвичайно складно. Сьогодні за умов тотального реформування системи охорони здоров'я України досить гостро стоїть питання ролі медичної сестри у виконанні місії як закладу охорони здоров'я, так і профілактики захворюваності та реабілітації хворих [1]. Питання обліку залишається основою для фінансового та економічного аналізу діяльності закладу і, як показує практика, в основному проводиться саме медсестрами. Сьогодні все частіше піднімається питання електронного обліку, що і $\epsilon$ головним інноваційним елементом системи. Саме цим проблемам і присвячена робота.

Основна частина. Інновації (від італ. innovatione новизна, нововведення) - нові форми організації діяльності та управління, нові види технологій, які охоплюють різні сфери життєдіяльності людства.

Одним із напрямків реформи охорони здоров'я $\epsilon$ впровадження електронного реєстру пацієнтів і перехід на електронний облік всієї діяльності системи

(c) О. І. Гарасимів, 2017 охорони здоров'я, що і зумовлює мету роботи, яка полягає в обґрунтуванні інноваційних впроваджень електронного обліку для підвищення результативності діяльності закладу охорони здоров'я за умов невизначеності реформування системи охорони здоров'я.

На виконання даної мети були поставлені завдання вивчення теоретичних засад інноваційних підходів до обліку в закладах охорони здоров'я, аналіз видів обліку та проблем, які виникають під час проведення його медсестрами, визначення можливостей закладів охорони здоров'я до запровадження електронного реєстру як інноваційного методу обліку медсестрами.

Електронний реєстр пацієнтів - це лише частина глобальної інформаційної системи медичної допомоги. Структура такої системи має превентивну складову, діагностику, власне лікування та реабілітаційну складову. Якщо розглядати кожного громадянина як потенційного пацієнта, то такий електронний реєстр замінить собою і перепис населення і статистичні служби та й, зрештою, і органи державної реєстрації актів цивільного стану і паспортні столи... 3 позицій держави - це була б досить вигідна справа зробити один єдиний такий реєстр, який містив би повну інформацію про громадянина і кошти на нього не розпи- 
лювалися 6 між різними відомствами та й інформація 6 не дублювалась. До речі, медична складова такого реєстру була 6 найбільшою і найдинамічнішою [2].

якщо йдеться лише про медичний реєстр, який починатиметься лише з хворого пацієнта, то його неможливо буде використовувати для запобігання захворюваності, хіба, що заднім числом для статистичного аналізу захворюваності та побудови прогнозів на цих даних.

Звичайно, єдиний реєстр пацієнтів на стадії розробки можна «нашпигувати» інформацією, яка буде слугувати не лише інформаційною базою наявності тієї чи іншої патології у пацієнта, а й переліком препаратів, які він приймає і тими, що йому призначає лікар, і обліком відповідних до протоколів лікування призначень, маніпуляцій та втручань і фіксацією результатів лікування цих хворих тощо. Відповідно, що наявність такої інформації дозволить планувати витрати на медичну допомогу відповідно до реальних споживчих потреб хворих [3]. Можна буде контролювати діяльність лікаря на адекватність і відповідність протоколам лікування. Можна буде обліковувати обсяг наданої медичної допомоги, а звідси вже і оплату лікарю, як пропонує сьогодні МОЗ.

Варто відзначити, що електронний облік, впроваджений в окремому лікувальному закладі чи установі, також має ряд позитивних моментів, починаючи від значного збільшення динамічності використання даних, статистичної обробки, підведення підсумків, оперативності реагування та інших важливих моментів використання, і закінчуючи миттєвими можливостями копіювання, зберігання і доступу до архівних даних.

\section{СПИСОК ЛІТЕРАТУРИ}

1. Інноваційні форми післядипломної підготовки організаторів охорони здоров'я в Україні: перший досвід / Ю. В. Вороненко, Н. Г. Гойда, Є. Є. Латишев [та ін.] // Сучасні медичні технології. - 2013. - № 2. - С. 27-29.

2. Литвинова О. Н. Що переважить на терезах реформ: рішучість чи мудрість? / О. Н. Литвинова // Ваше здоров'я. - 2017. - 13 січня. - С. 10-11.
Такий облік дає можливість значно ефективніше використовувати облікові дані для оперативної роботи управлінського персоналу.

Також слід відзначити такий момент, як прозорість використання облікових цінностей, відсутність можливостей корегування даних заднім числом, можливість стратегічного планування тощо.

Роль середнього медичного персоналу у веденні електронного обліку виражено зростає і потребує оволодіння ними механізму роботи з такими реєстрами. Залучення медсестер до ведення електронного обліку значно спростить діловодство, підніме на вищий професійний рівень достовірність облікової інформації, якісно підвищить повноту обліку тощо.

Попри численні зручності такого реєстру - збереження та повнота медичної інформації, оперативність їі обміну, можливість статистичних досліджень, тощо, існує і ряд застережень та цілий ряд юридичних колізій [4].

У будь-якому випадку створення такого реєстру вимагатиме вкладення немалих коштів. Тому перше, 3 чим потрібно визначитися це з метою такого реєстру і балансом «затрати - результат», або, як кажуть у народі «чи варта шкірка виправки».

Висновки. Проведені дослідження допоможуть готувати заклад охорони здоров'я до роботи за умов реформування, а медсестер для роботи за умов електронного обліку. Електронний облік у закладах охорони здоров'я $є$ необхідною, своєчасною і невідворотньою інновацією, яка лежить в основі реформування всієї системи охорони здоров'я. Роль медсестер за умов впровадження електронного обліку в закладах охорони здоров'я є провідною і найдоцільнішою.

3. Про затвердження Порядку ведення електронного реєстру пацієнтів Вінницької, Дніпропетровської, Донецької областей та м. Києва : наказ МОЗ України від 30 серпня 2012 p. № 666.

4. Про захист персональних даних (Відомості Верховної Ради України (ВВР), 2010, № 34, ст. 481) : Закон України. 